\title{
Sifat Kepahlawanan Tokoh Bujang dalam Novel Pulang Karya Tere Liye
}

\section{Heroism Traits as Presented by Bujang in Tere Liye's Novel "Pulang"}

\author{
Nita Maya Valiantien ${ }^{1, *}$ dan Setya Ariani ${ }^{2}$ \\ ${ }^{1,2}$ Fakultas Ilmu Budaya Universitas Mulawarman \\ ${ }^{1}$ Corresponding email: myvaliantien@fib.unmul.ac.id \\ ${ }^{2}$ Email: setya.ariani@fib.unmul.ac.id
}

\begin{abstract}
This study aims to provide an overview of heroic traits shown by the character Bujang in Tere Liye's novel "Pulang". The method used in analyzing the data is the qualitative method because the data collected and analyzed are in the form of narratives and dialogues in the text related to the heroic traits possessed by Bujang as the main character in the novel. Furthermore, this study uses descriptive techniques to define the heroic traits found in Bujang's character. From the analysis results, it was found that Bujang in the novel "Pulang" possessed eight heroic traits. The traits include caring, charismatic, inspiring, reliable, resilient, selfless, smart, and strong. This finding shows that heroic traits can be found in characters involved in the world of crime and in literary works that use the setting and themes of the criminal world. By having these eight heroic traits, Bujang represents a hero even though he is a character who has a role in the criminal world he lives in the novel.
\end{abstract}

Keywords: heroism traits, character, novel

\begin{abstract}
Abstrak: Penelitian ini bertujuan untuk memberikan gambaran tentang sifat-sifat kepahlawanan yang ditunjukkan oleh tokoh Bujang dalam novel Pulang karya Tere Liye. Metode yang digunakan dalam melakukan analisis terhadap data adalah metode kualitatif. Data yang dikumpulkan dan dianalisis berupa narasi maupun dialog dalam teks yang berkaitan dengan gambaran sifat-sifat kepahlawanan yang dimiliki oleh Bujang sebagai tokoh utama dalam novel Pulang. Lebih lanjut, penelitian ini menggunakan teknik deskriptif dalam memaparkan gambaran tentang sifat-sifat kepahlawanan yang ditemukan dalam tokoh Bujang. Dari hasil analisis, ditemukan delapan sifat kepahlawanan yang dimiliki oleh Bujang dalam novel Pulang Delapan sifat tersebut adalah: peduli, karismatik, inspiratif, terpercaya, tangguh, tanpa pamrih, pintar, dan kuat. Kedelapan sifat ini ditemukan dari awal hingga akhir cerita pada novel Pulang dan memiliki keterkaitan antara satu dengan yang lainnya. Temuan ini menunjukkan bahwa dengan memiliki delapan sifat kepahlawanan tersebut, tokoh Bujang merupakan representasi sosok pahlawan meskipun ia merupakan tokoh yang memiliki peran dalam dunia kriminal yang dijalaninya dalam novel Pulang.
\end{abstract}

Kata kunci: sifat kepahlawanan, karakter, novel

To cite this article:

Valiantien, N. M., \& Ariani, S. (2021). Sifat Kepahlawanan Tokoh Bujang dalam Novel Pulang Karya Tere Liye. Diglosia: Jurnal Kajian Bahasa, Sastra, dan Pengajarannya, 4(4), 499-514. https://doi.org/10.30872/diglosia.v4i4.242

\section{A. PENDAHULUAN}

Salah satu fungsi karya sastra adalah sebagai alat komunikasi yang dapat digunakan baik dalam sebuah kelompok maupun antar individu. Melalui karya sastra, terdapat proses penyampaian pesan lewat teks yang dilakukan oleh pengirim pesan kepada penerima pesan (Kartikasari, 2021). Pesan yang disampaikan sering kali merupakan cerminan peristiwa yang ada di masyarakat. Salah satu nilai dalam 
kehidupan yang tercermin melalu karya sastra dan hingga saat ini masih banyak dijadikan inspirasi dalam pembuatan karya sastra adalah nilai kepahlawanan. Karya sastra yang mengusung tema kepahlawanan sangat banyak ditemui baik dalam bentuk lisan maupun tulisan. Kepahlawanan memiliki kedudukan penting dalam ruang lingkup personal maupun kelompok atau organisasi termasuk juga negara (Azri \& Agung, 2017). Dengan mengetahui pentingnya nilai kepahlawanan, maka akan muncul harapan tentang kebaikan, terdapat peningkatan semangat dan persahabatan yang menjadi sebab dari dunia sebagai tempat hidup yang lebih baik karena adanya lebih banyak kebaikan-kebaikan yang terjadi (Kinsella et al., 2015) .

Menurut Franco et al. (2011), definisi pahlawan ditentukan oleh konteks yang meliputi situasi dan budaya. Secara umum, arti pahlawan adalah "sosok yang menonjol karena keberanian dan pengorbanannya dalam membela kebenaran; pejuang yang gagah berani" (KBBI, 2016). Menurut Goethals \& Allison kisah yang menceritakan aksi kepahlawanan memberikan contoh tentang hal yang berkaitan dengan kebijaksanaan serta tentang bagaimana seseorang dapat menjalani hidupnya atau dapat mencontoh hal yang seharusnya bisa dijalankan (Allison \& Green, 2020).

Terkait dengan aksi kepahlawanan, Goethals \& Allison (2012) membagi sifat kepahlawanan menjadi delapan ciri utama yang membentuk karakter pahlawan yang terdiri atas: peduli, karismatik, inspiratif, terpercaya, tangguh, tanpa pamrih, pintar, dan kuat. Untuk masing-masing ciri utama ini, Goethals \& Allison secara lebih spesifik memberikan indikator bagi masing-masing ciri tersebut, seperti yang disajikan dalam Tabel 1.

Tabel 1. Delapan Sifat Kepahlawanan (Goethals \& Allison, 2012)

\begin{tabular}{cll}
\hline No. & Ciri & Indikator \\
\hline 1 & Peduli & penuh kasih, empati, baik \\
2 & Karismatik & berdedikasi, fasih, bergairah \\
3 & Inspiratif & mengagumkan, menakjubkan, besar, inspirasional \\
4 & Terpercaya & setia, benar \\
5 & Tangguh & memiliki pencapaian, memiliki tekad yang kuat, tekun \\
6 & Tanpa pamrih & altruistik, rendah hati, bermoral \\
7 & Pintar & cerdas, bijaksana \\
8 & Kuat & berani, mendominasi, gagah, pemimpin \\
\hline
\end{tabular}

Dalam karya sastra, sering kali ditemukan bahwa tokoh pahlawan merupakan pengembangan tokoh yang awalnya hanya memiliki latar belakang yang biasa saja menjadi seseorang dengan peran yang patut diperhitungkan dan akhirnya berjasa dan dianggap menjadi pahlawan. Tidak jarang pula, untuk membuat karya sastra lebih menarik, nilai-nilai kepahlawanan dimasukkan ke dalam latar atau tema cerita yang dianggap bertolak belakang dengan konsep pahlawan pada umumnya.

Salah satu karya sastra yang menggambarkan nilai kepahlawanan tokoh utamanya dengan latar dunia kejahatan adalah novel Pulang karya Tere Liye. Pada novel ini, tokoh utama yang dikenal dengan nama Bujang digambarkan sebagai seorang tokoh yang menonjol dan dalam beberapa bagian di novel tersebut diceritakan bahwa Bujang berperan sebagai pejuang yang gagah berani membela kelompoknya yang merupakan bagian dari organisasi kriminal dunia. Pada novel ini, Tere Liye secara unik menyuguhkan latar dunia hitam, di mana secara umum dunia hitam sering dikaitkan dengan hal yang buruk. Akan tetapi dalam dunia kejahatan 
yang digambarkan dalam novel ini, Bujang muncul sebagai tokoh pahlawan, yaitu seseorang berjuang dengan gagah berani.

Terdapat beberapa penelitian terdahulu telah melakukan analisis terhadap novel Pulang karya Tere Liye dengan topik penelitian dan pendekatan yang berbedabeda. Beberapa penelitian tersebut antara lain dilakukan oleh Qolik (2016) yang memfokuskan pada analisis unsur intrinsik yang terdapat dalam novel Pulang, nilainilai sosiologi sastra hegemoni Gramsci dan penggunaan novel tersebut sebagai media pembelajaran kelas XI. Selain itu, Misbah (2017) melakukan analisis struktural dan mengkaji nilai pendidikan sosial yang terdapat dalam novel yang sama, dan Rahmayanti \& Arifin (2020) kembali melakukan analisis tentang nilai pendidikan yang disertai dengan analisis tentang gaya bahasa pada novel Pulang.

Dengan adanya beberapa penelitian yang telah dilakukan sebelumnya terkait dengan analisis novel Pulang karya Tere Liye, maka penelitian ini akan memaparkan hal yang tidak menjadi fokus pada penelitian-penelitian sebelumnya. Fokus penelitian ini adalah nilai kepahlawanan yang dimiliki oleh tokoh Bujang sebagai tokoh utama dalam novel Pulang. Dari pemaparan latar belakang tentang nilai kepahlawanan dan kehadiran nilai kepahlawanan dalam karya sastra, tujuan penelitian ini adalah menemukan nilai-nilai kepahlawanan yang secara langsung maupun tidak langsung tercermin melalui tokoh Bujang.

\section{B. METODE}

Penelitian ini merupakan penelitian kualitatif karena bertujuan untuk memiliki pemahaman mendalam tentang suatu gejala, fakta, atau realitas (Raco, 2010). Pemahaman tersebut dilakukan melalui proses observasi yang kemudian diikuti dengan melaporkan hasil pengamatan sebagaimana adanya. Secara khusus, penelitian ini menelaah tokoh Bujang sebagai tokoh utama pada novel Pulang terutama terkait sifat-sifat kepahlawanan yang dimilikinya.

Menurut Patton (2002), penelitian kualitatif merupakan jenis penelitian yang menggunakan data berupa kutipan, pengamatan, atau nukilan dari dokumen yang diteliti Data yang dianalisis dalam penelitian ini berupa narasi maupun dialog dalam teks yang ada pada novel, baik yang ditunjukkan langsung oleh tokoh Bujang atau melalui tokoh-tokoh lain yang terdapat di dalam novel Pulang. Narasi maupun dialog yang dijadikan sebagai data adalah yang menggambarkan sifat-sifat kepahlawanan menurut Goethals \& Allison (2012) dan sesuai dengan indikator yang ada.

Dalam proses pengumpulan data, terdapat beberapa tahapan yang pertama dimulai dengan membaca dan memahami keseluruhan cerita di dalam novel. Selanjutnya, dilanjutkan dengan memilih narasi maupun dialog yang sesuai dengan kriteria sifat-sifat kepahlawanan berdasarkan teori yang digunakan dan mengelompokkan data tersebut sesuai dengan kategori sifat-sifat kepahlawanan yang ada. Pada tahap analisis data, keseluruhan data yang telah terkumpul akan dideskripsikan sesuai dengan teori dan dibahas secara rinci keterkaitan antara teks dengan sifat-sifat kepahlawanan yang ada.

\section{PEMBAHASAN}

Setelah melakukan proses membaca secara menyeluruh novel Pulang dan melakukan identifikasi teks yang terkait dengan nilai-nilai kepahlawanan yang tercermin melalui tokoh Bujang, terdapat delapan sifat kepahlawanan yang sesuai dengan kriteria yang disampaikan oleh Goethals \& Allison (2012). Pembahasan 
tentang sifat-sifat tersebut akan secara rinci dijelaskan melalui penjelasan potonganpotongan cerita yang ada pada novel tersebut.

\section{Peduli}

Sifat peduli mencakup sifat penuh kasih, baik dan empati Sifat peduli sebagai salah satu nilai yang dimiliki oleh pahlawan memiliki makna sebagai sikap yang mengindahkan; memperhatikan; menghiraukan (KBBI, 2016). Menurut Juwaini (2010), seseorang yang memiliki rasa kepedulian akan berusaha untuk memberikan inspirasi yang juga termasuk perubahan dan kebaikan kepada lingkungan di sekitarnya. Zubaedi menjelaskan bahwa Kepedulian merupakan sikap memperhatikan orang lain, mengayomi dan menghiraukan (dalam Sauri, 2020). Kepedulian juga diartikan sebagai sikap yang dimiliki seseorang yang dapat berupa rasa toleransi dan rasa perhatian yang muncul (Nurlinda et al., 2013).

Dalam novel Pulang, Bujang merupakan pemuda dari pelosok desa yang diangkat menjadi anak oleh lelaki tua yang dikenal sebagai Tauke Besar, seorang pemimpin organisasi hitam dari Keluarga Tong. Tauke Besar sendiri memutuskan untuk mengangkat Bujang sebagai anak karena Samad-ayah kandung Bujangpernah mendedikasikan masa mudanya bekerja sebagai tukang pukul yang melindungi keluarga Tauke Besar. Dalam sebuah bagian cerita, digambarkan Bujang sebagai pemuda yang mampu menempatkan diri sebagai anak yang baik dan penuh kasih, termasuk kepada Tauke Besar sebagai ayah angkatnya. Pada narasi berikut, dapat terlihat bahwa Bujang berusaha untuk tetap berlaku lembut kepada Tauke Besar yang sedang marah kepadanya

"Tidak ada yang bilang begitu, Tauke." Aku berkata dengan suara lebih lembut, duduk di kursi samping ranjang, "Menemui calon presiden itu adalah pekerjaan yang Tauke berikan kepadaku, dan semua pekerjaan harus tuntas di keluarga ini, tidak terlambat walau sedetik. Tauke sendiri yang mendidik kami atau risikonya adalah hukuman" (Liye, 2015, p. 59).

Bagian ini menceritakan tentang Tauke Besar yang saat itu sedang kurang sehat dan meminta Bujang untuk segera menemuinya. Akan tetapi, Bujang terlambat datang dari waktu yang telah ditentukan oleh Tauke Besar sehingga membuatnya marah. Saat akhirnya Bujang datang untuk menemui Tauke Besar, Bujang menjelaskan alasan keterlambatannya adalah karena tugas yang diberikan oleh Tauke Besar. Di sini dapat diartikan bahwa Bujang memiliki rasa kasih sayang sehingga mau melaksanakan tugas yang diberikan oleh ayah angkatnya. Selain itu, cara Bujang berbicara dengan lebih lembut kepada Tauke Besar saat berusaha menjelaskan keterlambatannya juga menunjukkan bahwa Bujang memiliki sifat kasih sayang yang termasuk sebagai sifat peduli.

Memiliki empati juga merupakan bagian dari sikap peduli. Empati merupakan keadaan mental yang membuat seseorang merasa atau mengidentifikasi dirinya dalam keadaan perasaan atau pikiran yang sama dengan orang atau kelompok lain

Aku menyumpahi Basyir dalam hati. Siapa pula yang akan nyaman? Eksekusi itu berarti menghabisi seluruh penghuni rumah, termasuk anak-anak, wanita dan siapa saja yang ada di sana. Sejauh apa pun Tauke Besar membawa bisnis ini lebih terang dan bersih, sisi satu ini tidak pernah bisa ditinggalkan. Sisi itu 
seperti bayangan hitam pekat yang selalu mengikuti. Tidak bisa dipisahkan (Liye, 2015, p. 199).

Potongan teks di atas merupakan suara hati Bujang ketika Basyir-yang merupakan salah satu teman Bujang yang merupakan anggota organisasi kejahatan Keluarga Tong-menceritakan tentang rencana eksekusi ke suatu tempat. Dalam potongan teks di atas, Bujang tahu betul bahwa eksekusi tidak pernah akan dirasakan sebagai hal yang nyaman. Bujang paham bahwa eksekusi bukanlah hal yang baik karena hal tersebut melibatkan hal-hal buruk, termasuk menghilangkan nyawa manusia lain. Pada narasi ini terlihat bahwa Bujang mampu mengidentifikasi perasaan kelompok yang akan menerima eksekusi dan mampu mengalami perasaan yang sama dengan kelompok tersebut. Sehingga pada situasi ini, Bujang memiliki empati tersendiri terhadap kelompok yang akan menerima eksekusi dari kaki tangan Keluarga Tong meskipun pada saat itu Bujang tidak dapat berbuat lebih untuk menghentikan eksekusi yang akan dilakukan oleh Basyir dan anggota Keluarga Tong yang lain.

\section{Karismatik}

Termasuk sebagai sifat karismatik adalah berdedikasi, fasih, dan bergairah. Karismatik terkait dengan berkualitasnya seseorang. Dengan kualitas yang dimilikinya, seseorang bisa dipandang sebagai seorang pemimpin yang mampu mendeskripsikan kekuatan dirinya meskipun tanpa bantuan orang lain (Jamalulel, 2018). Karismatik berkaitan dengan karisma yang memiliki definisi sebagai sebuah keadaan atau bakat yang dihubungkan dengan kemampuan yang luar biasa dalam hal kepemimpinan seseorang untuk membangkitkan pemujaan dan rasa kagum dari masyarakat terhadap dirinya (KBBI, 2016). Secara garis besar, karismatik berkaitan dengan kepemimpinan seseorang yang terbentuk dari kualitasnya melalui pengabdian diri yang melibatkan pengorbanan tenaga, pikiran, dan waktu demi keberhasilan suatu usaha atau tujuan mulia. Tokoh Bujang di beberapa bagian cerita dalam novel Pulang menunjukkan tokoh dengan sifat karismatik melalui penggambaran atau ujaran dari tokoh lain.

Sifat karismatik Bujang tergambar dari ucapan ketua Lin saat Bujang mendatanginya langsung untuk menyelesaikan permasalahan antara keluarga Lin dan Keluarga Tong terkait pencurian chip yang dilakukan oleh anggota keluarga Lin.

Saat Bujang muncul, ketua keluarga Lin mengakui bahwa Bujang memiliki keberanian luar biasa dengan mendatanginya secara langsung.

"Reputasimu ternyata tidak omong kosong." Orang tua itu menatapku, "Malam ini, berani sekali kau datang ke sarang harimau seorang diri, mengganggu meditasi di ruangan favoritku. Aku bisa membunuhmu dengan mudah..." (Liye, 2015, p. 121).

Dengan mendatangi langsung, berarti Bujang memosisikan dirinya setara dengan ketua Liem yang merupakan pemimpin di keluarga tersebut. Pengakuan dari ketua Liem bahwa reputasi Bujang bukanlah hal yang omong kosong dan sekaligus menunjukkan bahwa Bujang telah secara luas diketahui sebagai orang yang tidak memiliki rasa takut pada siapa pun. Hal ini menguatkan anggapan bahwa Bujang merupakan sosok yang patut diperhitungkan dan tidak bisa dianggap sebelah mata. 
Hal tersebut selanjutnya bisa membangkitkan rasa kagum dan pemujaan dari orang lain sehingga dengan demikian Bujang memiliki karisma tersendiri.

Sifat karismatik Bujang secara tidak langsung dinyatakan oleh Tauke Besaryang merupakan ayah angkat Bujang melalui cuplikan cerita berikut.

"Itu jenius sekali, Bujang! "Tauke menepuk dahinya, seolah tidak percaya mendengar ide tersebut. "Kau benar. Kita dirikan saja banknya. Uang akan datang, persis seperti laron mengerubuti lampu. Tidak percuma kau kuliah di universitas terbaik Ibu Kota" (Liye, 2015, p.168).

Pada bagian cerita tersebut menunjukkan respons Tauke Besar terhadap ide Bujang. Di bagian ini, diceritakan bahwa Tauke besar sedang mencari strategi untuk melancarkan bisnis shadow economy nya. Bujang memberikan gagasan kepada Tauke untuk mendirikan bank Keluarga Tong sendiri untuk mendukung kegiatan organisasi yang dijalankan. Dengan menyebut Bujang sebagai sosok yang jenius, Tauke Besar mengungkapkan kekagumannya kepada Bujang. Dengan menyetujui ide Bujang, hal ini menunjukkan bahwa Bujang memiliki kemampuan untuk menjadi pemimpin yang usulannya layak untuk diikuti. Kemampuan ini berkaitan dengan sifat karismatik yang berkembang setelah Bujang melewati perjuangan panjang untuk belajar dan menuntut ilmu di tingkat yang lebih tinggi demi masa depan Keluarga Tong. Hal ini juga menunjukkan bahwa Bujang membangun sifat karismatiknya melalui pengabdiannya yang tulus kepada Keluarga Tong serta pengorbanan yang meliputi tenaga, pikiran, dan waktu untuk mencapai keberhasilan.

\section{Inspiratif}

Sifat lainnya yang terkait dengan nilai kepahlawanan adalah inspiratif atau bersifat menginspirasi (KBBI, 2016). Sifat ini terkait dengan kemampuan untuk memberikan dorongan dalam melakukan sesuatu. Menurut Trianto, inspiratif merupakan hal yang berkaitan dengan ide yang diciptakan oleh seseorang yang telah mendapat sebuah hasil dari suatu proses belajar dan sifat kepedulian terhadap lingkungan (Setiani \& Arifin, 2021). Dengan memiliki sifat inspiratif, seseorang dianggap memiliki ide besar dan hal lain yang mengagumkan sehingga dapat diikuti atau dijadikan sebagai contoh.

Berkaitan dengan sifat inspiratif, yang salah satunya terbentuk dari hal-hal yang menakjubkan yang dimiliki oleh seseorang, pada novel ini, Bujang, melalui pernyataan tokoh calon presiden yang saat itu ia temui, disebutkan sebagai tokoh yang memiliki kemampuan menakjubkan dengan berbagai hal besar yang ia miliki.

"Jika di adalah jagal dunia hitam, maka tidak pelak lagi, dia adalah jagal nomor satu. Jenius, kuat, dan tidak mengenal rasa takut. Semua ucapannya adalah kebenaran..." (Liye, 2015, p. 36).

Pernyataan bahwa Bujang adalah nomor satu, memiliki makna bahwa Bujang adalah seseorang dengan posisi teratas, terbaik. Selain itu, penyebutan Bujang sebagai orang yang jenius, kuat, dan tidak mengenal rasa takut merupakan gambaran tambahan tentang betapa tokoh Bujang memiliki banyak hal mengagumkan dalam dirinya. 
Hal lain yang menunjukkan bahwa Bujang adalah sosok yang inspiratif diceritakan saat Bujang yang baru menyelesaikan kuliahnya, pulang ke rumah Tauke Besar dan menyadari adanya koleksi baru yang berupa barang seni di rumah Tauke Besar.

"Sejak kapan Tauke mengumpulkan barang seni di rumah ini?" Aku bertanya, mencomot sembarang percakapan-karena sejak tadi mereka terus bertanya tentangku.

"Ah, itu," Mansur yang menjawab, "Sejak dua tahun lalu, Bujang. Kau yang memberikan kami ide."

Aku menatap tidak mengerti. Aku? Kapan aku bilang?

"Tidak secara langsung memang, tapi kau pernah menulis barang seni adalah salah satu investasi terbaik sekaligus cara mencuci uang (Liye, 2015, pp. 234235).

Mengoleksi barang seni merupakan kegiatan baru Tauke Besar yang baru ia mulai setelah membaca tulisan Bujang tentang mengumpulkan barang seni sebagai salah satu cara terbaik untuk berinvestasi sekaligus cara mencuci uang. Berdasarkan potongan cerita di atas, melalui pernyataan Mansur, Bujang merupakan sumber inspirasi dari kegiatan tersebut. Dalam kata lain, Bujang merupakan sosok inspiratif dibalik kegiatan mengoleksi benda-benda seni yang sebelumnya tidak pernah dilakukan oleh Tauke Besar. Hal ini secara jelas menggambarkan bahwa Bujang memiliki sifat inspiratif.

\section{Terpercaya}

Sifat terpercaya dapat terlihat dari kesetiaan dan kebenaran. Hal ini berarti seseorang yang memiliki sifat setia merupakan orang yang berpegang teguh pada janji, pendirian, dan sebagainya dan juga memiliki kepatuhan atau ketaatan pada suatu hal (KBBI, 2016). Terkait dengan salah satu indikator terpercaya yaitu kesetiaan, Budiyono menggambarkan bahwa orang dengan sifat setia merupakan sosok yang berpendirian teguh, taat dengan perjanjian atau keputusan hasil musyawarah bersama, taat pada orang tua, keluarga, suku dan bangsa, dan tidak mudah terbujuk oleh orang lain atau harta (Sulastri, 2019).

Beberapa bagian dalam novel ini menggambarkan bahwa sebagai seorang permuda yang telah diangkat menjadi anak oleh Tauke Besar, Bujang merupakan sosok yang terpercaya karena memiliki kesetiaan yang penuh terhadap Tauke Besar.

Aku menggeram. Aku tidak akan lari dari pertarungan, Jika malam ini aku ditakdirkan mati, maka aku akan mati dengan seluruh kehormatan. Pedangku teracung ke depan, aku akan memberikan perlawanan dengan sisa tenaga akhir (Liye, 2015, p. 297).

Tubuhku sebenarnya remuk, badanku dipenuhi oleh luka, tapi aku tidak akan meninggalkan Tauke Besar di sini, membiarkan dia ditemukan oleh Basyir atau putra tertua Keluarga Lin. Aku meraih tubuh Tauke. Aku akan menggendongnya keluar lorong. Kami harus bergegas pergi (Liye, 2015, p. 300). 
Dua cuplikan cerita di atas menggambarkan bagaimana Bujang berusaha untuk tetap menunjukkan ketaatannya kepada Tauke Besar sebagai orang yang selama ini telah memberikan banyak pengalaman dan kesempatan baru kepada Bujang semenjak Bujang diangkat sebagai anak. Pada saat terjadi pengkhianatan yang dilakukan oleh Basyir, Bujang berjuang sekuat tenaga untuk melindungi Tauke Besar. Bahkan pada saat seluruh tubuh Bujang sudah mengalami banyak luka dan melemah, Bujang tetap berusaha keras untuk menyelamatkan Tauke Besar. Hal ini hanya bisa dilakukan karena Bujang memiliki sifat setia yang besar kepada Tauke Besar.

Bagian cerita lain yang menunjukkan bahwa Bujang merupakan sosok yang terpercaya dapat dilihat melalui ucapan Salonga yang merupakan guru Bujang dalam mempelajari kemampuan menembak menggunakan pistol.

"Aku tahu kenapa kau mengangkatnya menjadi anak, Tauke." Salonga berdiri, "Pertama, tangannya sama sekali tidak gemetar saat mengacungkan pistol kepadaku. Dia selalu tenang dalam situasi genting apa pun. Kedua, kau benar, dia memiliki cara berpikir yang berbeda dibanding dengan tukang pukul lainnya. Kesetiaan anak ini ada pada prinsip, bukan pada orang atau kelompok..." (Liye, 2015, p. 187).

Potongan pernyataan Salonga ini terjadi saat Bujang berhasil melewati ujian terakhir yang diberikan oleh Salonga. Saat itu, Bujang diperintahkan untuk menembak Salonga menggunakan pistol yang sudah diisi beberapa butir peluru oleh Salonga. Tauke Besar yang hadir pada saat itu juga turut mendesak Bujang agar menembak Salonga sesuai dengan perintah. Akan tetapi, Bujang tidak menuruti perintah tersebut. Hal tersebut bukanlah karena Bujang tidak memiliki sifat setia dan patuh terhadap Tauke Besar, namun justru Bujang saat itu menunjukkan bahwa ia adalah pemuda yang memiliki keteguhan atas pendirian yang ia miliki selama ini dan ia menunjukkan komitmennya terhadap prinsip yang selama ini ia miliki, yaitu untuk tidak bertindak tanpa alasan yang tepat.

\section{Tangguh}

Tangguh memiliki arti di antaranya adalah kuat terutama berkaitan dengan pendirian, tabah dan tahan dengan penderitaan (KBBI, 2016). Sifat Tangguh yang dimiliki oleh Bujang dapat ditemukan di beberapa bagian cerita dalam novel ini. Bujang digambarkan sebagai sosok dengan sifat tangguh yang memiliki kekuatan fisik, ketekunan dalam mencapai suatu tujuan, dan pencapaian-pencapaian yang mengagumkan.

Pada suatu bagian awal pada novel ini, dikisahkan bahwa Bujang ditugaskan untuk menemui calon presiden dan memberikan peringatan agar calon tersebut tidak mengganggu kegiatan shadow economy yang dijalankan oleh keluarga Tong jika calon tersebut kelak terpilih menjadi presiden. Calon presiden tersebut mengetahui tentang Bujang dari pengalaman di masa lalunya yang pada saat itu merupakan mahasiswa yang menempuh masa kuliah di kampus yang sama dengan Bujang.

"... Tidak ada yang tahu latar belakang keluarganya. Semua serba misterius. Tapi bukan itu hal mengerikan tentangnya. Di tahun kedua, saat aku masih di sana, kampus kami kedatangan atlet lari cepat pemegang rekor dunia. Pemuda 
itu menantang atlet itu untuk lomba lari. Hanya beberapa orang yang menyaksikannya di stadion kampus yang tertutup, dia mengalahkan atlet pemegang rekor dunia itu seperti mengalahkan anak kecil (Liye, 2015, pp. 3536).

Dari narasi yang diungkapkan oleh bakal calon presiden yang ditemui oleh Bujang, ia menggambarkan bahwa meskipun sosok Bujang sangat misterius, keberadaannya sangat patut untuk diperhitungkan, bahkan ucapannya harus diikuti. Pada narasi tersebut diceritakan bahwa Bujang memiliki kemampuan untuk menantang atlet lari cepat pemegang rekor dunia yang tidak perlu diragukan lagi kemampuannya. Akan tetapi ternyata Bujang dapat mengalahkan atlet tersebut dengan sangat mudah seperti mengalahkan anak kecil. Hal ini menunjukkan bahwa Bujang telah banyak berlatih ketangkasan dan kekuatan fisik sehingga menjadi pemuda yang tangguh

Sebagai remaja yang tidak pernah terlibat dengan aktivitas bersekolah di jenjang pendidikan dasar, Bujang diceritakan mampu untuk meraih pencapaian dengan mengejar ketertinggalannya hanya dalam waktu satu tahun. Bujang digambarkan sebagai remaja yang tekun dan banyak menghabiskan waktunya untuk belajar demi mencapai target untuk mendapatkan ijazah penyetaraan di tingkat Pendidikan dasar. Bujang akhirnya mampu mencapai target tersebut dengan nilai yang sempurna.

Siangnya aku berangkat sekolah. Bukan di sekolah sungguhan, tapi belajar dengan Frans di bangunan utama. Usiaku lima belas tahun, tapi aku sudah tertinggal sembilan tahun Pendidikan formal. Setiap kali selesai menemui Frans, aku membawa lebih banyak buku yang harus kubaca di kamar. Tapi ini berubah menyenangkan karena dengan bisa berlatih Bersama Kopong, aku tidak keberatan menghabiskan waktu membacanya... (Liye, 2015, p. 96).

Aku tidak pernah ikut satu pun pertempuran. Pertama, karena Tauke melarangku, dan itu tidak ada tawar-menawar. Kedua, aku sibuk dengan sekolahku. Satu tahun tinggal di sana, aku telah mendapatkan ijazah persamaan sekolah dasar dan sekolah menengah pertama. Nilai-nilaiku sempurna (Liye, 2015, p. 99).

Tidak berhenti di situ, pencapaian Bujang berlanjut saat ia melanjutkan pendidikan formalnya hingga ke universitas dan berhasil lulus dengan dua gelar master sekaligus dari universitas ternama.

"Dulu, kau sangat kesal saat harus mengerjakan tes dariku saat pertama kali kita bertemu. Hari ini, kau pulang membawa dua gelar master dari universitas ternama. Lihatlah, wajahmu terlihat percaya diri, tercermin dari caramu menatap, bicara, bersikap, dan bertindak. Kau belajar banyak, Bujang, tidak hanya dari Pendidikan formal, juga dari pengalaman. Itulah kenapa Tauke Besar mengirimmu jauh untuk sekolah. Hal yang pasti bermanfaat bagi Keluarga Tong (Liye, 2015, p. 227). 
Tentunya pencapaian Bujang sebagai pemuda dengan dua gelar master tersebut merupakan hasil dari ketekunannya selama di dunia kuliah. Selama menjadi mahasiswa, Bujang sangat antusias untuk menyerap berbagai pengetahuan terutama yang terkait dengan shadow economy dan menghabiskan banyak waktu untuk memperdalam tentang hal tersebut.

Aku menyukai dunia kuliah. Ini berbeda dengan belajar di rumah bersama Frans. Di sini aku menemui banyak orang, mengenal dosen-dosen terbaik untuk bertukar pikiran dan menambah wawasan, serta menemukan konsepkonsep menarik. Frans benar, belajar seperti bakat alamiahku. Salah satu pelajaran yang paling menarik bagiku adalah tentang shadow economy. Aku banyak membaca banyak buku tentang itu. Aku tak keberatan berjam-jam menghabiskan waktu di perpustakaan dan melakukan riset mendalam (Liye, 2015, p. 166).

\section{Tanpa pamrih}

Hal lain yang disebutkan sebagai sifat yang terkait dengan kepahlawanan adalah sifat tanpa pamrih. Pamrih sendiri berarti sebuah keadaan yang memiliki maksud yang tersembunyi dalam memenuhi keinginan untuk memperoleh keuntungan pribadi (KBBI, 2016). Hal ini berarti dengan memiliki sifat tanpa pamrih, seseorang tidak menyimpan maksud yang tersembunyi terutama dalam upaya mencapai tujuan atau keinginan pribadi. Selain digambarkan sebagai sosok yang setia, Bujang juga digambarkan memiliki sifat tanpa pamrih terhadap Tauke Besar dan keluarga Tong, sebagaimana terungkap pada kutipan berikut.

"Aku suka dengan anak muda ini. Kau benar-benar tidak memiliki rasa takut. Berapa Keluarga Tong membayarmu, hah? Akan aku lipat-gandakan jika kau mau bergabung bersamaku.

Aku menggeleng, "Tidak semua di dunia ini bisa dibeli dengan uang" (Liye, 2015, p. 122).

Potongan cerita tersebut terjadi saat Bujang menemui ketua keluarga Lin. Pada situasi tersebut, ketua Lin mengakui bahwa Bujang merupakan sosok yang sangat berani dan keberanian tersebut membuat ketua Lin tertarik untuk bisa mengajak Bujang untuk bergabung menjadi anggota organisasi keluarga Lin dengan menawarkan bayaran yang besar kepada Bujang. Akan tetapi Bujang bukanlah sosok yang mencari keuntungan untuk dirinya. Dengan sifat setia yang ia miliki kepada Tauke Besar dan keluarga Tong, Bujang secara terang-terangan menolak ajakan ketua Lin. Bujang dengan sikap tanpa pamrihnya tetap setia pada keluarga Tong dan patuh menjalankan misi yang diberikan kepadanya untuk menyelesaikan masalah dengan keluarga Lin.

Sifat tanpa pamrih di sisi lain terkait dengan sifat rendah hati dan bermoral. Memiliki kerendahan hati terkait dengan ketidaksombongan atau tidak meninggikan dirinya di atas orang lain. Sedangkan bermoral berarti memiliki pertimbangan baik buruk, sesuai dengan moral. Meskipun Bujang tumbuh dewasa dalam sebuah organisasi yang dijalankan dengan banyak keburukan dan kejahatan, namun tokoh Bujang tetap memiliki sifat rendah hati dan bermoral. Salah satunya ditunjukkan 
melalui potongan cerita saat Bujang akhirnya mengalahkan Basyir dalam upaya membalas pengkhianatan yang dilakukan Basyir.

"Menyerahlah, Basyir. Aku tidak akan menyakitimu. Kau akan dibiarkan pergi dengan aman. Aku sungguh minta maaf atas kejadian puluhan tahun lalu, saat Tauke Besar membakar rumah kau. Jika aku bisa membalik waktu, aku sendiri yang akan membatalkan kejadian itu agar kau tetap punya orang tua, punya ibu yang bisa membacakan pepatah lama setiap malam. Tapi aku tidak bisa melakukannya. Aku tahu rasanya kehilangan orangtua, Basyir. Menyesakkan. Menyakitkan" (Liye, 2015, p. 392).

Pada bagian ini, diceritakan bahwa setelah melakukan perlawanan dan pertahanan yang sangat hebat terhadap serangan Basyir hingga Basyir kepayahan untuk kembali berdiri, Bujang memberikan kesempatan terakhir kepada Basyir untuk menyerah. Bujang bisa saja menghabisi nyawa Basyir pada saat itu, akan tetapi sifat bermoral membuatnya membiarkan Basyir untuk pergi dengan aman. Dalam potongan cerita ini juga tampak Sifat rendah hati Bujang saat menyatakan permintaan maaf kepada Basyir atas kejadian buruk yang menimpanya di masa lalu. Meskipun Bujang telah menjadi pemenang dalam perlawanan terhadap Basyir, namun tetap Basyir tidak merasa memiliki kedudukan yang lebih tinggi dari Basyir. Sebagai seorang teman, Bujang tetap memiliki rasa rendah hati dan ikut berempati atas apa yang dialami oleh Basyir.

\section{Pintar}

Menurut Taufik (2019), orang yang pintar memiliki pengetahuan yang luas karena kemampuannya memahami apa pun dengan baik dan juga memiliki kedisiplinan dan keteraturan dalam hidupnya sehingga selalu memiliki kemampuan untuk mengerjakan sesuatu yang diperintahkan. Dalam novel ini, meskipun awalnya Bujang hanyalah anak dari kampung terpencil yang tidak pernah mendapat pendidikan formal, akan tetapi tokoh Bujang digambarkan sebagai tokoh yang memiliki sifat pintar dan cerdas. Hal ini dapat dilihat dari penggambaran tokoh lain tentang Bujang.

"Semoga kau sukses dengan sekolahmu, Bujang." Basyir memegang lenganku menatapku tersenyum. "Kalau saja aku pintar sepertimu, aku mungkin lebih memilih pergi sekolah daripada menjadi tukang pukul... (Liye, 2015, p. 213).

Pernyataan Basyir tersebut terjadi saat Bujang ditugaskan untuk melanjutkan pendidikan ke jenjang yang lebih tinggi. Basyir sendiri ditugaskan untuk menjalani latihan fisik di gurun bersama salah satu kelompok suku Arab di sana. Pada pernyataan tersebut, Basyir mengakui bahwa Bujang adalah sosok yang memiliki kepintaran lebih dari dirinya. Basyir sendiri juga menyatakan bahwa jika dia memiliki kepintaran seperti Bujang, tentu ia akan memilih bersekolah daripada menjadi tukang pukul.

Pernyataan lain yang menunjukkan sifat cerdas yang dimiliki oleh Bujang adalah pernyataan calon presiden yang ditemui oleh Bujang. 
"Aku tahu pemuda itu,sedikit. Dia satu kampus denganku di Amerika, menyelesaikan dua master sekaligus empat short course dalam waktu singkat. Dia lulus dengan nilai sempurna... (Liye, 2015, pp. 35-36).

Dari potongan pernyataan di atas, Bujang digambarkan sebagai sosok yang luar biasa dan cerdas karena dapat menyelesaikan beberapa kegiatan akademis dalam waktu yang singkat. Menyelesaikan pendidikan untuk meraih dua gelar master sekaligus merupakan sebuah pencapaian yang luar biasa, ditambah lagi dengan empat short course dan semuanya mendapatkan nilai akhir yang sempurna. Hal tersebut hanya memungkinkan untuk dilakukan oleh orang-orang yang pintar. Potongan cerita ini menggambarkan bagaimana Bujang adalah sosok yang pintar dan memiliki kecerdasan yang tinggi.

\section{Kuat}

Seseorang yang dianggap memiliki nilai kepahlawanan juga digambarkan sebagai seseorang yang kuat. Kuat sendiri berkaitan dengan gagah yang memiliki definisi bertenaga, memiliki kemampuan untuk melakukan sesuatu (KBBI, 2016). Dengan memiliki sifat kuat, seseorang juga memiliki keberanian dan mampu memosisikan dirinya dengan tugas sebagai pemimpin. Sehingga orang dengan sifat kuat juga akan mampu mendominasi di tengah-tengah orang lain. Budiyono (dalam Alimin \& Sulastri, 2018) menjelaskan bahwa keberanian adalah kualitas jiwa yang tidak mengenal rasa takut pada kritik, tetapi membuat orang melanjutkannya dengan ketenangan dan ketabahan dalam menghadapinya.

Pada novel Pulang, karakter Bujang sebagai tokoh yang kuat digambarkan di awal cerita saat ia pergi ke dalam hutan untuk berburu di malam hari bersama Tauke Besar dan rombongannya yang datang dari kota.

Malam itu, di tengah hujan deras, di tengah rimba lebat lereng Bukit Barisan, hanya aku yang masih sehat. Hanya aku yang masih bisa berdiri untuk menghalangi pimpinan kawanan babi menghabisi semuanya.

Aku mencengkeram tombak pemberian Bapak. Aku berdiri dengan kaki kokoh, menatap ke depan dan bersitatap dengan monster mengerikan itu. Aku tidak punya pilihan. Lari sia-sia saja karena gerakan babi ini cepat sekali. Aku juga tidak akan meninggalkan begitu saja yang lain dalam keadaan terluka. Maka jika aku harus mati, aku akan memberikan perlawanan terbaik (Liye, 2015, p. 19).

Melalui cuplikan cerita di atas, dapat dipahami bahwa pada saat itu situasi sangat berbahaya bagi Bujang serta bagi Tauke Besar dan rombongannya. Di dalam hutan rimba lebat di malam hari, sekelompok babi hutan berukuran besar berusaha menyerang mereka. Dalam usaha melawan babi hutan yang menyerang mereka, akhirnya hanya tinggal Bujang seorang diri yang masih kokoh bertahan, sementara rombongan yang lain sudah mengalami luka dan tidak mampu melanjutkan perlawanan. Saat itu Bujang masih berusia lima belas tahun, usia yang masih cukup muda untuk memiliki kekuatan dan keberanian menghadapi situasi seperti yang dihadapinya. Tetapi justru Bujang digambarkan sebagai tokoh yang gagah karena masih kokoh setelah melawan babi hutan dan tidak mengenal takut untuk 
menghadapi bahaya akan dihadapinya. Bahkan Bujang bertekad untuk memberikan perlawanan yang terbaik.

Dengan memiliki sifat kuat, Bujang juga digambarkan mampu mendominasi sebagai pemimpin, terutama saat merencanakan perlawanan terhadap pengkhianatan Basyir dan saat telah berhasil melumpuhkan pengkhianatan Basyir kepada Keluarga Tong. Pada saat membuat rencana untuk melumpuhkan pengkhianatan Basyir, Bujang meminta dan bahkan memberikan perintah kepada beberapa orang, termasuk White yang merupakan anak Frans, guru Bujang. White sendiri merupakan mantan marinir yang berpengalaman dengan misi berbahaya.

"Aku sedang bersembunyi, Menyusun rencana. Aku membutuhkan bantuanmu, White. Kau harus segera ke Ibu Kota, siang ini juga. Bawa seluruh senjata dan amunisi yang kau punya. Juga panggil teman-temanmu mantan marinir yang masih aktif menerima misi berbahaya. Berapa pun yang bisa kau bawa, mereka akan dibayar mahal..." (Liye, 2015, p. 350).

Cuplikan tersebut menceritakan tentang Bujang yang menghubungi White dan memintanya untuk membantu Bujang melakukan perlawanan terhadap Basyir. Bujang tidak hanya meminta, tapi sebagai sosok yang kuat, Bujang juga mampu memberikan perintah langsung kepada White tentang apa saja yang harus dilakukan. Hal ini menunjukkan bahwa Bujang mendominasi dalam rencana-rencana terkait perlawanan yang akan dilakukan kepada Basyir.

Sifat mendominasi Bujang semakin tampak saat akhirnya Basyir dan komplotannya dapat dikalahkan. Sepeninggal Tauke Besar yang telah wafat semenjak serangan pengkhianatan Basyir, maka otomatis Bujanglah yang menggantikan peran Tauke Besar sebab tidak ada keturunan yang dimiliki oleh Tauke Besar untuk melanjutkan organisasi keluarga Tong. Pada saat perlawanan terhadap Basyir telah selesai, Bujang langsung memberikan instruksi kepada Parwez untuk mengatur keadaan seperti semula.

"Kita menang, Bujang."

"Ya. Kau pastikan tidak ada operasional bisnis legal yang terganggu karena kejadian ini, Parwez." Aku langsung memberi perintah, "Besok seluruh kantor perusahaan harus kembali dibuka. Adakan konferensi pers, pastikan cerita versimu sama dengan versi Togar. Semoga harga saham perusahaan kita di bursa efek dunia tidak terkoreksi akibat menghilangnys kau dua hari terakhir dan begitu banyaknya insiden yang melibatkan Gedung ini" (Liye, 2015, p. 397).

Pada akhirnya, Bujang menjadi kepala Keluarga Tong dengan menyandang gelar Tauke Besar. Dengan demikian, Bujang menjadi pemimpin dan penentu utama berbagai hal terkait dengan usaha yang dilakukan oleh keluarga Tong, termasuk menentukan haluan baru yang akan dituju oleh usaha Keluarga Tong. Bujang akan semakin mendominasi di dunia yang ia jalani sejalan dengan kekuatan dan sifat kepemimpinan yang ia miliki.

Aku kepala Keluarga Tong sekarang, memimpin ribuan anggota keluarga dan puluhan perusahaan yang tersebar di seluruh Kawasan Asia Pasifik. Aku bisa 
menentukan haluan baru ke mana keluarga penguasa shadow economy ini akan dibawa.

Akulah Tauke Besar (Liye, 2015, p. 398).

Dari keseluruhan proses analisis data yang berkaitan dengan sifat-sifat kepahlawanan yang ditunjukkan oleh tokoh Bujang pada novel Pulang, ditemukan bahwa kedelapan sifat kepahlawanan yang dikategorisasikan oleh Goethals dan Allison (2012) telah digambarkan sejak awal mula cerita, kemudian bertambah sejalan dengan berkembangnya cerita, dan tetap ada hingga di bagian akhir cerita pada novel Pulang. tergambar pada tokoh Bujang. Penggambaran tentang sifat-sifat kepahlawanan yang ada pada diri Bujang ditemukan secara langsung pada tokoh Bujang maupun penggambaran melalui tokoh lain yang ikut berperan dalam cerita pada novel Pulang. Kedelapan sifat kepahlawanan yang terdapat pada tokoh Bujang memiliki keterkaitan antara satu dengan yang lain sehingga ketika semuanya digabungkan, terdapat gambaran yang utuh tentang tokoh Bujang sebagai seorang pahlawan.

\section{PENUTUP}

Setelah melakukan proses data, dapat disimpulkan bahwa tokoh Bujang dalam novel Pulang memenuhi kriteria delapan sifat kepahlawanan. Delapan sifat tersebut adalah: peduli, karismatik, inspiratif, terpercaya, tangguh, tanpa pamrih, pintar, dan kuat. Kedelapan sifat ini dapat dijumpai mulai awal hingga akhir cerita pada novel Pulang dan memiliki keterkaitan antara satu dengan yang lainnya. Temuan ini menunjukkan bahwa dengan memiliki delapan sifat kepahlawanan tersebut, tokoh Bujang merupakan representasi sosok pahlawan meskipun ia merupakan tokoh yang memiliki peran dalam dunia kriminal yang dijalaninya dalam novel Pulang karya Tere Liye.

\section{DAFTAR PUSTAKA}

Alimin, A. A., \& Sulastri, S. (2018). Nilai Keberanian dalam Novel Negeri di Ujung Tanduk Karya Tere Liye. Jurnal Pendidikan Bahasa Dan Sastra Indonesia, 3(1), 15.

Allison, S. T., \& Green, J. . (2020). Nostalgia and Heroism: Theoretical Convergence of Memory, Motivation, and Function. Frontiers in Psychology, 11, 1-13. https://doi.org/doi: 10.3389/fpsyg.2020.577862

Azri, B. Y., \& Agung, I. M. (2017). Pahlawan: Siapa Mereka? Pendekatan Psikologi Indigenous. Jurnal Psikologi Sosial, 15(2), 95-104. https://doi.org/doi: 10.7454/jps.2017.9

Franco, Z. E., Blau, K., \& Zimbardo, P. . (2011). Heroism: A Conceptual Analysis and Differentiation Between Heroic Action and Altruism. Review of General Psychology, 15(2), 99-113. https://doi.org/doi: 10.1037/a0022672

Goethals, G. R., \& Allison, S. T. (2012). Making Heroes: The Construction of Courage, Competence, and Virtue. UR Scholarship Repository. https://scholarship.richmond.edu/cgi/viewcontent.cgi?article=1089\&context =jepson-faculty-publications

Jamalulel, H. A. (2018). Peran Kepemimpinan Karismatik Kiai dalam Pembentukan Karakter Santri di Pondok Pesantren Darul Muttaqien Kabupaten Bogor. Institutional 
Repository UIN Syarif Hidayatullah Jakarta. https://repository.uinjkt.ac.id/dspace/handle/123456789/43407

Juwaini, A. (2010, August 24). Peduli Adalah.... Kompas. https://nasional.kompas.com/read/2010/08/24/01134533/ Oase Jeda?pa ge $=$ all.

KBBI. (2016). "Karisma". https://kbbi.kemdikbud.go.id/entri/karisma

KBBI. (2016). "Inspiratif". https://kbbi.kemdikbud.go.id/entri/inspiratif

KBBI. (2016). "Kuat". https://kbbi.kemdikbud.go.id/entri/kuat

KBBI. (2016). "Pahlawan". https://kbbi.kemdikbud.go.id/entri/pahlawan

KBBI. (2016). "Pamrih". https://kbbi.kemdikbud.go.id/entri/pamrih

KBBI. (2016). "Peduli". https://kbbi.kemdikbud.go.id/entri/peduli

KBBI. (2016). "Setia". https://kbbi.kemdikbud.go.id/entri/setia

KBBI. (2016). "Tangguh". https://kbbi.kemdikbud.go.id/entri/tangguh

Kartikasari, E. (2021). Nilai Budaya dalam Serat Ajisaka. Diglosia: Jurnal Kajian Bahasa, Sastra, Dan Pengajarannya, 4(2), 177-188. https://doi.org/https://doi.org/10.30872/diglosia.v4i2.139

Kinsella, E. L., Ritchie, T. D., \& Igou, E. R. (2015). Zeroing in on heroes: A prototype analysis of hero features. J. Pers. Soc. Psychol, 108, 114-127. https://doi.org/10.1037/a0038463

Liye, T. (2015). Pulang. Republika Penerbit.

Misbah, S. (2017). Analisis Struktural Dan Nilai Pendidikan Sosial Dalam Novel Pulang Karya Tere Liye. Repository Universitas PGRI Yogyakarta. http://repository.upy.ac.id/id/eprint/1655

Nurlinda, Martono, \& Wartiningsih. (2013). Nilai-Nilai Dalam Novel Partikel Karya Dewi Lestari (Dee). Jurnal Pendidikan Dan Pembelajaran Khatulistiwa, 2(2), 1-17.

Patton, M. (2002). Qualitative Research and Evaluation Methods. Sage Publication, Inc.

Qolik, N. (2016). Analisis Nilai Sosiologi Sastra Pada Novel Pulang Karya Tere Liye Dan Skenario Pembelajarannya Di Kelas XI SMA. Jurnal Surya Bahtera., 4(40). http://ejournal.umpwr.ac.id/index.php/surya-bahtera/article/view/3722

Raco, J. . (2010). Metode Penelitian Kualitatif: Jenis, Karakteristik dan Keunggulannya. PT Gramedia Widiasarana Indonesia.

Rahmayanti, W., \& Arifin, Z. (2020). Analisis Gaya Bahasa dan Nilai Pendidikan dalam Novel Pulang Karya Tere Liye. Diskursus: Jurnal Pendidikan Bahasa Indonesia, 3(1), 77-85.

Sauri, S. (2020). Nilai-Nilai Sosial Dalam Novel Hujan Karya Tere Liye Sebagai Bahan Pembelajaran Kajian Prosa Pada Mahasiswa Program Studi Diksatrasiada Universitas Mathla'ul Anwar Banten. Literasi: Jurnal Penelitian Bahasa Dan Sastra Indonesia Serta Pembelajarannya, 4(1), 38-45.

Setiani, F., \& Arifin, Z. (2021). Nilai Edukatif Tokoh Burlian Dalam Novel Si Anak Spesial Karya Tere Liye: Tinjauan Sosiologi Sastra Sebagai Bahan Ajar Cerita Inspiratif. Jurnal Pendidikan, Bahasa, Sastra, Seni, Dan Budaya, 2(1), 1-12.

Sulastri, S. (2019). Representasi Nilai Kesetiaan Dalam Novel Negeri Di Ujung Tanduk Karya Tere Liye. Jurnal Pendidikan Bahasa, 8(2), 269-280.

Taufik, M. (2019, April 9). Pintar dan Cerdas Itu Beda. https://itjen.kemdikbud.go.id/public/post/detail/pintar-dan-cerdas-itubeda. $\% 0 \mathrm{~A} \% 0 \mathrm{~A}$ 
